\title{
PERBANDINGAN PROSES PENGASAPAN IKAN CAKALANG MENGGUNAKAN ALAT KONVENSIONAL DAN LEMARI PENGASAPAN DI DESA DARUBA PANTAI KABUPATEN PULAU MOROTAI
}

\section{The Comparison of Fumigating Fish Process Using Conventional Equipment and Fumigating Cabinets in the Daruba Pantai Village of Morotai Island District}

\author{
Iswandi Wahab ${ }^{1}$, Juwita Kore ${ }^{1}$, dan Rinto M Nur ${ }^{1}$ \\ 1) Fakultas Perikanan dan Ilmu Kelautan, Universitas Pasifik Morotai \\ Email : iswandi.fpik@gmail.com
}

\begin{abstract}
Abstrak
Ikan merupakan produk usaha tangkap perikanan yang mudah membusuk dan cepat rusak, sehingga sering diawetkan. Terhadap beberapa cara untuk mengawetkan ikan, salah satunya dengan cara pengasapan. Pada umumnya masyarakat Kabupaten Pulau Morotai melakukan proses pengasapan ikan secara tradisional. Tujuan penelitian ini adalah untuk mengetahui dan menggunakan proses pembuatan ikan asap dengan alat konvensional dan lemari pengasapan dalam pengolahannya di Desa Daruba Pantai, Kabupaten Pulau Morotai. PKL ini dilakukan pada bulan September 2019 di tempat Bapak Rahim dan mengukur efisiensi. Tahap pengasapan ikan dengan alat konvensional dan lemari pengasapan di Desa Daruba Pantai secara umum sama. Proses ikan asap meliputi ikan dibelah, dibuang isang dan isi perut, dicuci, dijepit dengan bambu, dicuci kembali, disiangi, diasap dan dioles minyak. Membutuhkan bahan bakar lebih banyak (30kg) dibandingkan dengan menggunakan lemari pengasapan (15kg). Selain itu, waktu pengasapan dengan menggunakan alat konvensional lebih lama (4-8 jam) dibandingkan dengan menggunakan lemari pengasapan (2-3 jam). (Kata kunci:ikan cakalang asap, alat Konvensional, dan Lemari pengasapan).
\end{abstract}

Kata Kunci: Ikan Cakalang Asap, Alat Konvensional, dan Lemari Pengasapan.

\begin{abstract}
Fish is a fishing product, which is easy to rot and is easily damaged, so it is often preserved. There are several ways to preserve fish, one of which is by fumigating. In general, the people of island Morotai district carry out traditional fumigating fish processes. The purpose of this study was to determine and use the process of making smoked fish with conventional tools and fume cupboards in its processing in Daruba Pantai Village, Morotai Island district. This research was conducted in September 2019, at Mr. Rahim's place. The phase offish fumigation with conventional tools and fume cupboard in Daruba Pantai Village is generally the same. The fumigation fish process involves splitting the fish, removing the contents of the stomach and stomach contents, washing, clamping with bamboo, washing again, then weed, fumigating and smeared oil. The fumigating fish process with conventional tools requires a lot of fuel (30kg) compared to using fume hood $(15 \mathrm{~kg})$.Besides, the fumigating time using conventional tools is longer (4-8 hours) than using the fumigating cabinets (2-3 hours).
\end{abstract}

Keywords: Skipjack Tuna, Conventional Tools, and Fumigating Cabinets. 


\section{PENDAHULUAN}

Ikan merupakan bahan makanan yang mengandung protein yang berkualitas tinggi.Protein dalam kandungan ikan tersusun atas-asam amino essensial yang diperlukanoleh tubuh sebagai sumber energi. Membantu pertumbuhan, pemeliharaan tubuh, memperkuat daya tahan tubuh, dan memperlancar proses fisiologis dalam tubuh, di banding dengan produk hewani lainya. Ikan memiliki beberapa kelebihan seperti memiliki kandungan protein yang cukup tinggi (20\%), mudah dicerna oleh tubuh, mengandung asam-asam lemak tak jenuh dengan kadar kolestrol yang rendah, dan mineral seperti $\mathrm{K}$, $\mathrm{Ci}, \mathrm{P}, \mathrm{S}, \mathrm{Mg}, \mathrm{Fe}, \mathrm{Zn}, \mathrm{Cu}$, vitamin A dan D. Selain memiliki banyak kelebihan, ikan juga memiliki beberapa kekurangan. Ikan memiliki salah satu bahan makanan yang mudah membusuk, bila tidak langsung diberi perlakuan dan penanganan yang tepat setelah ditangkap mutunya akan cepat (Warsidi, 2009). Hal ini disebabkan oleh ikan mengandung air yang cukup tinggi sehingga cepat rusak dan mengalami pembusukan.

Adawya (2008), menjelaskan bahwa dalam waktu 8 jam sejak ikan ditangkap dan didaratkan sudah akan timbul timbul perubahan yang mengarah pada kerusakan. Kerusakan yang terdapat pada ikan dapat menghambat usaha pemasaran hasil perikanan, tidak jarang menimbulkan kerugian besar terutama ketika produksi ikan melimpah. Oleh sebab itu, diperlukan proses pengawetan dan pengolahan untuk mempertahankan ikan dari proses pembusukan sehingga mampu disimpan lama, meningkatkan jangkauan pemasaran, Pelaksanakan diversifikasi pengolahan produk-produk perikanan, dan meningkatkan pendapatan. Untuk meningkatkan nilai tambah, baik dari segi, rasa, bau, bentuk/tekstur maupun daya awet ikan perlu ditangani atau diolah dengan baik.

Hasil penelitian Soejono (2008) menunjukkan bahwa pengolahan ikan kering dapat meningkatkan nilai tambah sebesar 29-65\%. Menurut Irianto (2005) pengawetan ikan adalah pengawetan dengan tujuan untuk mempertahankan mutu serta mencegah terjadinya pembusukan ikan. Selain itu, juga untuk mempertahankan mutu kesegaran ikan selama mungkin dengan cara menghambat atau menghentikan sama sekali, penyebab kemunduran mutu, pembusukan maupun penyebab kerusakan ikan. Pengawetan ikan dapat dilakukandengan beberapa teknik, baik yang menggunakan teknologi tinggi maupun teknologi yang sederhana.
Palm et al (2011) menjelaskan bahwa pengasapan dapat didefinisikan sebagai proses penestrasi senyawa volatil pada ikan yang dapat dihasilkan dari pembakaran kayu. Pengasapan dilakukan dalam dua tahap yaitu pangasapan panas dan pengasapan dingin. Pengasapan panas (hot smoking) adalah proses pengasapan ikan dimana ikan akan di asapi diletakkan cukup dekat dengan sumber asap. Suhu pengasapan ini sekitar $70-100^{\circ} \mathrm{C}$ dengan lamanya pengasapan $2-4$ jam. Suhu pengasapan yang tinggi mengakibatkan enzim menjadi tidakaktif sehingga dapat mencegah kebusukan. Suhu pengasapan yang dingin menonaktifkan pertumbuhan enzim pembusuk ikan dan membuat ikan menjadi cepat matang (Sulistijowati, 2011).

Sedangkan pengasapan dingin (cold smoking) adalah pengasapan dengan cara meletakan ikan yang akan diasap (tempat pembakaran kayu), dengan suhu sekitar 40-50 ${ }^{0} \mathrm{C}$ dengan lama proses pengasapan beberapa hari sampai dua pekan. Menambahkan pengertian tersebut pengasapan dingin merupakan cara pengasapan pada suhu rendah, yaitu tidak lebih tinggi dari suhu $33{ }^{0} \mathrm{C}$ sekitar $15-33{ }^{0} \mathrm{C}$. waktu pengasapannya dapat mencapai 4-6 pekan. Penggunaan suhu rendah dimaksudkan agar ikan tidak menjadi masak atau protein didalamnya tidak terkoagulasi (Kusmajadi et al., 2011).

Di Morotai, umumnya masyarakat melakukan pengolahan ikan asap dengan mengunakan metode secara tradisional dan alat yang sederhana untuk melakukan pengasapan ikan. Kelemahan-kelemahan yang ditimbulkan oleh pengasapan tradisional antra lain kenampakan kurang menarik, kontrol suhu sulit dilakukan dan mencemari udara atau polusi (Swastawati, 2011). Pada beberapa desa di morotai, pengasapan ikan dilakukan dengan menggunakan lemari pengasapan. Keuntungan penggunaan lemari pengasapan adalah suhu ruang lemari asap dapat diatur, asap tidak menyebar, bahan bakar lebih ekonomis kenampakan produk lebih baik, dan produk yang dihasilkan lebih kering (Suryaningrum dan Mujianah., 2009).

\section{METODE PENELITIAN}

\section{Waktu dan Tempat Penelitian}

Penelitian ini dilaksanakan pada bulan September 2019 diindustri pangasapan ikan milik Bapak Rahim di Desa Daruba Pantai, Kecamatan Morotai Selatan, Kabupaten Pulau Morotai. 


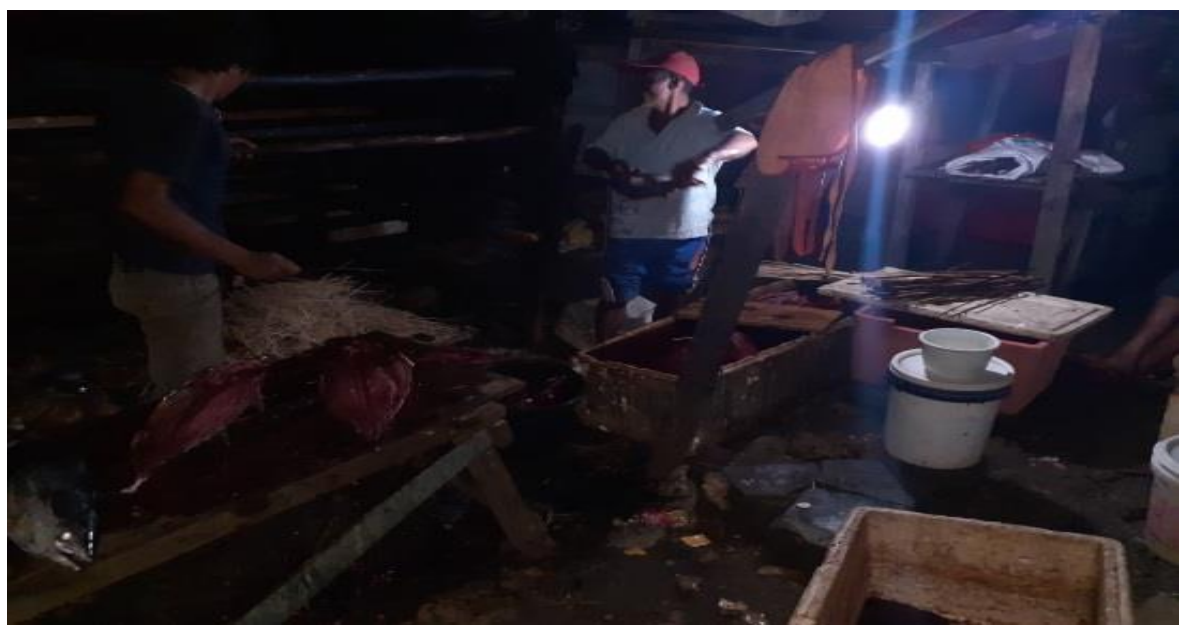

Gambar 1. Peta Lokasi Penelitian

\section{Metode Penelitian}

Alat yang digunakan dalam penelitian ini adalah alat tulis untuk menulis, angket untuk wawancara narasumber (pelaku usaha), kamera untuk dokemtasi, alat pengasapan sederhana, lemari pengasapan, pisau, baskom, penjempit. Bahan yang digunakan ikan, air dan sabut kelapa dan bambu.

Prosedur dalam pengambilan data adalah sebagai berikut.

a. Survey awal untuk menentukan lokasi atau narasumber.

b. Wawancara dengan narasumber (pelaku usaha) menggunakan angket

c. Pengamatan langsung perbandingan proses pembuatan ikan asap konvensional dan lemari pengasapan.

d. Penilaian sensori ikan.

\section{Analisis Data}

Data yang diperoleh dari lapangan disajikan dalam bentuk diagram alir dan gambar serta dianalisis secara deskriptif.

\section{HASIL DAN PEMBAHASAN}

\section{Gambaran Umum Tempat Usaha Ikan Asap}

Tempat usaha ikan asap milik Bapak Rahim terletak di complex Desa Daruba Pantai, Kecematan Morotai Selatan, Kabupaten Pulau Morotai. Usaha ikan asap ini masih dalam skala industry rumah tangga yang pengolahannya dilakukan oleh Bapak Rahim sendiri dan dibantu oleh dua orang kariyawan. Industry rumah tangga ini masih sangat sederhana dan pengolahan ikan asap yang dilakukan secara tradisional / konvensional. Industry rumah tangga ini berdiri sejak tahun 2008 hingga sekarang.

Bahan baku yang digunakan dalam pengolahan ikan asap adalah ikan cakalang. Bahan baku diperoleh dari pedagang pengecer maupun langsung dari nelayan tangkap. Selain bahan baku berupa ikan, dalam usaha ini juga dibutuhkan beberapa bahan seperti kayu bakar (Gonofu dan sabut gargaji), air bersi, bambu, danminyakgoreng. Peralatan yang digunakan selama proses pengasapan ikan berupa baskom, pisau, parang, cool box, dan talanan (dari kayu). Tempat pengasapan masih sangat sederhana tiang dari kayu, atap seng dan tanpa dinding. Tempat pengasapan berukuran $2 \times 1,5 \times 2,5$ $\mathrm{m}^{3}$. Tempat pengasapan terdiri dari 3 rak. Jarak antara sumber api kerak pertama $\pm 1 \mathrm{~m}$ dan jarak rak pertama ke rak kedua $\pm 0,5 \mathrm{~m}$. Dalam sekali produksi biasanya. Bapak Rahim memproduksi 60-200 ekor ikan asap.

Pengasapan dilakukan setiap hari, namun volumenya tergantung kondisi penjualan pada hari itu. Pembuatan dan uji coba lemari pengasapan ikan, sosialisasi dan penelitian cara pengoperasian lemari pengasapan ikan, pendampingan proses produksi ikan asap, evaluasi dan diakhiri dengan melaporkan dan publikasi. Tepatnya pada hari senin (26/8/2009), tim PKMS melakukan sosialisasi menyerahan lemari pengasapan kepada Bapak Rahim di tempat produksi ikan asap tempatnya di Desa Daruba Pantai.

\section{Proses Pembuatan Ikan Asap \\ a. Persiapan Ikan}

Proses pengasapan ikan dilakukan oleh Bapak Rahim, sebelum diasapi ikan disiapkan terlebih dahulu. Proses pengasapan dibuang isang dan isi perut, dicuci, dijepit dengan bambu, ikan dicuci kembali, disiangi, diasap. Rorano dan Nur (2019), melaporkan bahwah Ikan dibelah di bagian punggung setelah dibelah isang dan isi perut dibuang (Gambar 2a), dan selanjutnya ikan dicuci (Gambar 2b), ikan dicuci menggunakan air bersih. Pencucian bertujuan untuk menghilangkan sisa-sisa kotoran dan darah ikan yang masih menempel di daging ikan. Tahap selanjutnya yaitu penjepitan ikan bertujuan untuk menjaga agar ikan tidak hancur selama proses 
pengasapan. Ikan kembali dicuci ditujuk fungsi untuk menujuk ikan dari kepala sampai pangkal ekornya tetapi tidak sampai tembus tujuanya agar ikan

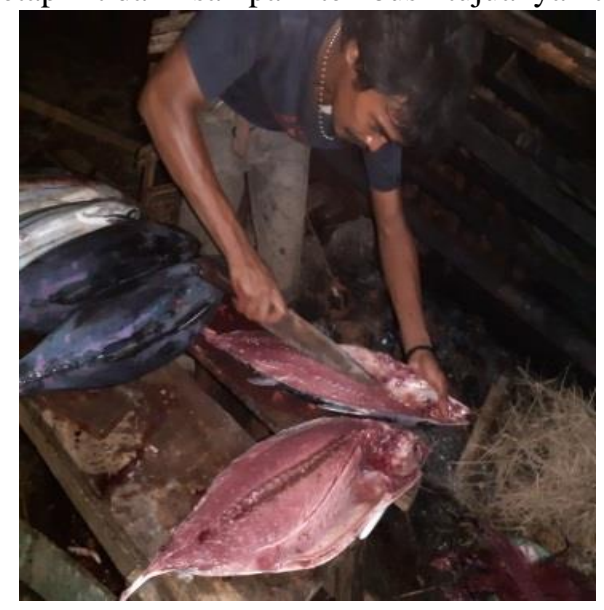

$\mathbf{a}$

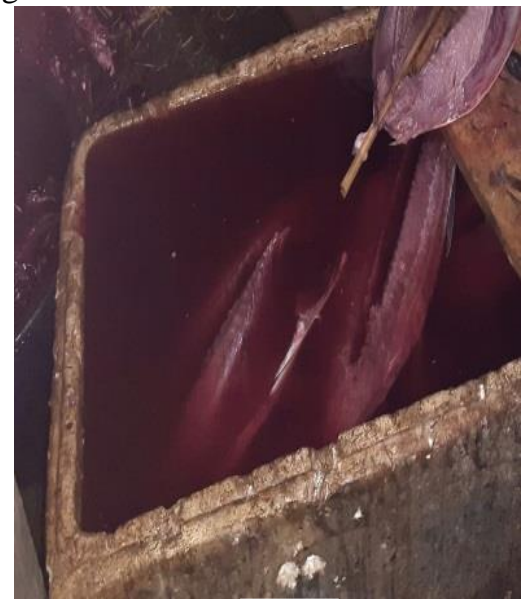

b

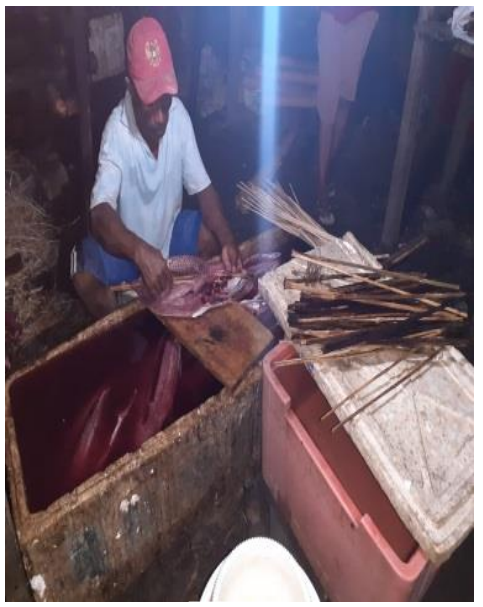

c

Gambar 2. (a. Ikan Dibelah, b. Pencucian Ikan Setelah Dibelah, c. Ikan Ditujuk dan Dijepit dengan Bambu)

\section{b. Proses Pengasapan}

Dilakukan dengan metode pengasapan panas. Tujuan dari pengasapan adalah untuk mengawetkan dan memberi warna serta rasa spesifik pada ikan. Daya pengawet asap yang terbatas (tergantung pada lama dan ketebalan asap). Pengasapan secara tradisional juga menyebabkan banyak senyawa metabolit sekunder (sentawa organik) melekat pada permukaan ikan. Swatawati et al (2013) melaporkan bahwa kandungan fenol, formaldehid dan asam organik lebih tinggi dengan pengasapn tradisional dibandingkan pengasapan modern (smoking cabinet). Senyawa organic inilah yang memberikan rasa khas terhadap ikan. tersebut adalah agar ikan dapat dengan mudah dibalik.

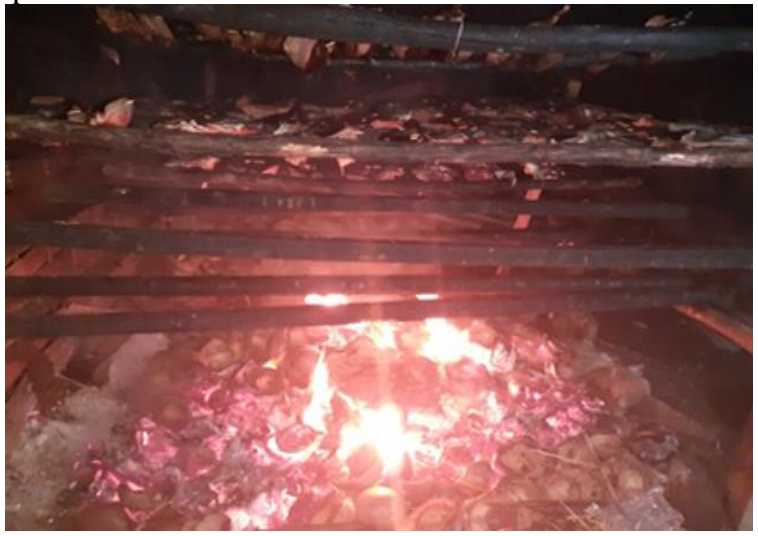

Gambar 3. Proses Pengasapan Ikan

2) Ikan yang telah matang (Gambar 4) diangkat dan didinginkan. Selanjutnya ikan diolesi dengan minyak goreng pada permukaan ikan. Proses ini dilakukan agar ikan tampak mengkilat dan menarik. Selain itu, pengolesan minyak goreng
Ikan yang telah disiapkan selanjutnya disusun diatas rak pengasapan pada alat pengasapan konvensional maupun lemari pengasapan, pengasapan dengan menggunakan alat konvensional membutuhkan bahan bakar (sabut dan tampurung kelapa) sebanyak $(30 \mathrm{~kg})$ dalam sekali produksi. Selain itu, waktu yang dibutuhkan dalam proses pengasapn hingga ikan matang sempurna selama 4-8 jam.

1) Pengasapan dengan alat konvensional ini banyak tidak termanfaatkan secara optimal untuk mengasap/mematangkan ikan karena menyebar dan hilang ke udara. 


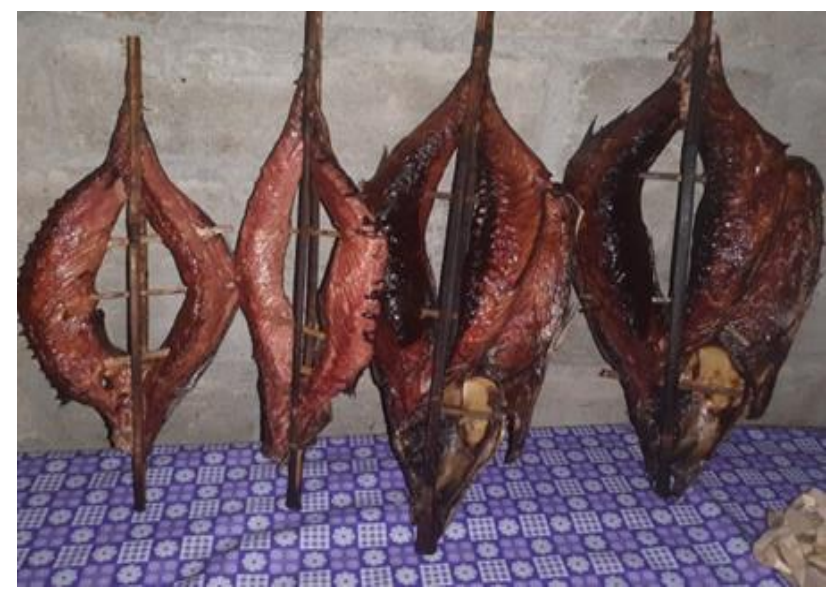

Gambar 4. Ikan Siap Dipasarkan

Penggunaan lemari pengasapan ini juga dapat menghemat penggunaan bahan bakar $(15 \mathrm{~kg})$ karena alat yang digunakan tipe lemari/cabinet sehingga asap danpanas yang dihasilkan terperangkap di dalam. Alat ini juga dilengkapi dengan pengukur suhu dan jumlah asap dalam lemari pengasapan dapat dikontrol. Selain itu, penggunaan lemari pengasapan ini membuat proses pengasapan lebih higienis karena tertutup sehingga udara dan debu tidak mudah mengenai ikan yang diasapi.

Kondisi asap dalam proses pengasapan juga sangat ditentukan oleh kondisi bahan bakar, pengaturan nyala dengan lemari api mempengaruhi

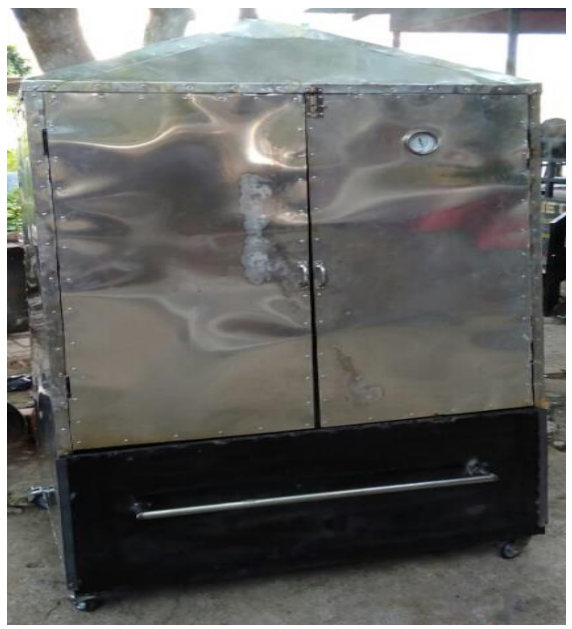

Gambar 5. Alat Lemari Pengasapan Ikan

Penggunaan lemari pengasapan adalah suhu ruang lemari pengasapan tidak menyebar, bahan bakar lebih ekonomis, kenampakan produk lebih baik, dan produk yang dihasilkan lebih kering. Pengasapan dengan lemari pengasapan tidak terpengaruh oleh angin karena dapur api tertutup dan diberi vantilasi udara, pengasapan dapat diatur dengan membuka dan menutup (dumper) pada cerobong asap. pembentukan asap. Pada awal pengasapan sebaiknya suhu rendah sehingga asap lebih banyak yang menempel pada daging ikan dalam kondisi basah. Namun, sulitnya mengontol nyala api menyebabkan peningkatan suhu pada jam pertama sangat tinggi mencapai hampir $90^{\circ} \mathrm{C}$. Penggunaan sabut dan tampurung kelapa cukup baik dalam menghasilkan asap dan panas sehingga walaupun pada awal pengasapan suhu agak sulit dikontrol namun pembentukan asap sudah dapat membuat tampilan ikan menjadi lebih menarik (warna kuning keemasan).

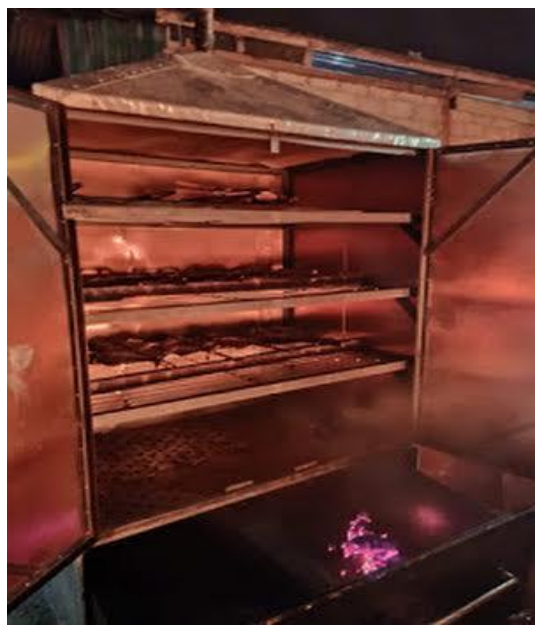

Produk yang diasap dengan menggunakan lemari pengasapan lebih kering, warna produk lebih kuning dan mengkilat, asap lebih tajam (Suryaningrum dan Muljanah, 2009) ikan asap yang diolah menggunakan lemari pengasapan warnanya lebih cerah, teksturnya lebih kering, bauh asap lebih tajam dan tampilan lebih baik. Selain itu, pengasapan dengan menggunakan lemari pengasapan membutuhkan waktu 2-3 jam hingga ikan matang sempurna. 


\section{KESIMPULAN DAN SARAN}

\section{Kesimpulan}

Dari hasil penelitian dapat disimpulkan sebagai berikut.

a. Tahap pengasapan ikan dengan alat konvensional dan lemari pengasapan di Desa Daruba Pantai. Secara umum sama. Proses pembuatan ikan asap meliputi ikan dibelah, dibuang isang dan isi perut, dicuci, dijepit dengan bambu, dicuci kembali, disiangi, diasap dan diolesi minyak.

b. Membutuhkan bahan bakar lebih banyak $(30 \mathrm{~kg})$ dibndingkan dengan menggunakan lemari pengasapan $(15 \mathrm{~kg})$, selain itu, waktu pengasapan dengan menggunakan konvensional lebih lama (4-8 jam dibandingan dengan menggunakan lemari pengasapan (2-3 jam).

\section{Saran}

Berdasarkan hasil penelitian yang diperoleh, maka disarankan perlu dilakukan penelitian lanjutan untuk melihat berapa lama waktu penyimpanan produk ikan asap

\section{DAFTAR PUSTAKA}

Adawyah. 2007. Pengolahan dan Pengawetan Ikan., Prinsip Pengasapan. Bumi Aksara, Jakarta.

Adawyah, R. 2008. Pengolahan dan Pengawetan Ikan. PT. Bumi Aksara. Jakarta.

Afrianto E, Liviawaty E, 1991. Pengawetan dan Pengolahan Ikan. Kanisius: Yogyakarta.

Badan Standarisasi Nasional (BSN). 2013 Standar Nasional Indonesia 2725: 2013 Tentang Ikan Asap dengan Pengasapan Panas. Jakarta.

Danial M, M Tawil, Wahidah. 2012. Upaya Mempertahankan dan Meningkatkan Nilai Gizi dan Nilai Organoleptis Pangan Hasil Laut melalui Teknologi Pengolahan Ikan. Jurnal Sainsmat. 61(8) : 1064-1070.

Ghozali, Thomas, Muchatadi D, Yaroh. 2004. Peningkatan Daya Tahan Simpan Ikan 6(1). Bandung.

Heruwati ES. 2002. Pengolahan Ikan secara Tradisional: Prospek dan peluang Pengembangan. Jurnal Litbang Pertanian, 21(2). 92-99.

Husen A, dan Ruslan A. Daeng. 2018. Pengaruh Lama Penyimpanan Terhadap Mutu Ikan Cakalang Asap (Katsuwonus pelamis). Jurnal AGRIKAN 11(2), E-ISSN 2598-8298/P-ISSN 1979- 6072.
Ibrahim N, Sulistijowati R, Mile L. 2014. Uji Mutu Ikan Cakalang Asap dari Unit Pengolahan Ikan di Provinsi Gorontalo. Jurnal Ilmiah Perikanan dan Kelautan: 2(1).

Irawan, 1997, Pengawetan dan Pengolahan Ikan, CV. Aneka, Solo.

Kusmajadi, S., Lilis S., dan Balqis B. 2011. Keempukan Dan Akseptabilitas Daging Ayam Pada Berbagai Temperatur Dan Lama Pengasapan. Jurnal Ilmu Ternak. 11(1).

Maryono, Sudding, Rahmawati. 2013. Pembuatan dan analisa mutu briket arang tempurung kelapa ditinjau dari kadar kanji. Jurnal Chemica. $14: 74-83$.

Nawawi, Zamanhuri, Napitupulu, Syuhada, 2008, Kajian Karakteristrik Perpindahan Panas pada Ruang Sistem Pengering/Pengasapan dengan Energi Panas dari Bahan Bakar Jurnal Polimesin. 9(9) : 532-544.

Nyoman, S, dkk. 2007. Perikanan. SIC. Surabaya. SNI 2725.1 2009. Standar Nasional Indonesia tentang Ikan Asap. Badan Standarisasi Nasional. Jakarta.

Rorano, M dan Nur, R.M. 2019. Sanitasi dan Higiene Pengolahan Ikan Tuna dan Cakalang Asap DiTanah Tinggi Desa Gotalamo Kabupaten Pulau Morotai. Jurnal Aksara Publik. 3(2): 134-141.

Sudarmaji S, Hariyono B, dan Suhardi. 2003. Analisa Bahan Makanan dan Pertanian. Liberty. Yogyakarta. $171 \mathrm{hlm}$.

Swastawati F., Surti T., Agustini T.W., Riyadi P.H. 2013. Karakteristik Ikan berbeda. Jurnal Aplikasi Teknologi Pangan. 2(3): 126-132.

Utomo, B.S., Wibowo S., dan Widianti T.N. (2012). Asap Cair, Cara membuat dan aplikasinya pada pengolahan ikan asap.

Wardana, 2008, Bahan Bakar dan Teknologi Pembakaran, PT. Danar Wijaya, Brawijaya University Prees, Universitas Brawijaya Malang.

Warsidi, E. 2009. Bagaimana Mengolah dan Mengawetkan Ikan. Mitra Utama. Bekasi.

Wibowo S,. 2000. Industri Pangasapan Ikan. Penebar Seadaya. Jakarta.

Yusra, Efendi Y. 2010. Dasar-Dasar Teknologi Hasil Perikanan. Bung Hatta University Press. Padang. 